\title{
Intestinal inflammation modulates expression of $11 \beta$-hydroxysteroid dehydrogenase in murine gut
}

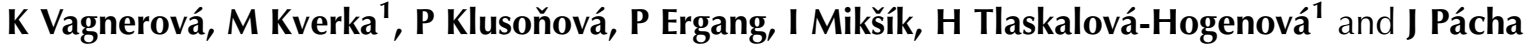 \\ Institutes of Physiology and ${ }^{1}$ Microbiology, Czech Academy of Sciences, Vídenská 1083, CZ-142 20 Prague 4, Czech Republic \\ (Requests for offprints should be addressed to J Pácha; Email: pacha@biomed.cas.cz)
}

\begin{abstract}
The effect of glucocorticoids is controlled at the pre-receptor level by the activity of $11 \beta$-hydroxysteroid dehydrogenase (11HSD). The isoform $11 \mathrm{HSD} 1$ is an $\mathrm{NADP}^{+}$-dependent oxidoreductase, usually reductase, that amplifies the action of glucocorticoids due to reduction of the biologically inactive 11-oxo derivatives cortisone and 11-dehydrocorticosterone to cortisol and corticosterone. The $\mathrm{NAD}^{+}$-dependent isoform (11HSD2) is an oxidase that restrains the effect of hormones due to $11 \beta$-oxidation of cortisol and corticosterone to their 11-oxo derivatives. Although the immunosuppressive and anti-inflammatory effects of glucocorticoids are well known, the relationship between inflammation and local metabolism of glucocorticoids is not well understood. In this study, we
\end{abstract}

demonstrated that colitis induced by dextran sulfate sodium modulates colonic 11HSD1. Experimentally induced intestinal inflammation stimulated colonic $\mathrm{NADP}^{+}{ }^{-}$dependent but not $\mathrm{NAD}^{+}$-dependent $11 \mathrm{HSD}$ activity. Colonic $11 \mathrm{HSD} 1 \mathrm{mRNA}$ was increased, whereas $11 \mathrm{HSD} 2 \mathrm{mRNA}$ was not changed. Additional parallel studies revealed a similar pattern of 11HSD1 mRNA induction in mesenteric lymph nodes and intestinal intraepithelial lymphocytes, but not in spleen and peritoneal macrophages. These data suggest that inflammation modulates local metabolism of glucocorticoid and support the notion that pre-receptor regulation of endogenous corticosteroids might play a role in inflammatory processes.

Journal of Endocrinology (2006) 191, 497-503

\section{Introduction}

Glucocorticoids are known to be essential modulators of immune and inflammatory processes. They influence the development and effector functions of the immune system, trafficking of immune cells through the vascular bed, and chemotaxis. At the cellular level, they modulate maturation, differentiation, proliferation, and activation of immune cells (Ashwell et al. 2000, Webster et al. 2002). One of the main effects of glucocorticoids is the downregulation of pro-inflammatory cytokines. These cytokines, such as tumor necrosis factor $\alpha$ (TNF- $\alpha$ ) and interleukin-1 (IL-1), have been shown to link inflammation with glucocorticoid production by stimulating the hypothalamic-pituitary-adrenal axis and elevating thereby the plasma glucocorticoid concentration (Besedovsky \& del Rey 1996). However, the biological activity of glucocorticoids depends not only on their plasma concentration, the number of receptors, and the responsiveness of the target cell, but also on the local metabolism of glucocorticoids catalyzed by $11 \beta$-hydroxysteroid dehydrogenase (11HSD), which can change the concentration of active glucocorticoids within tissues and/or target cells.

Two isoforms of 11HSD have been characterized. Isoform $2(11$ HSD 2$)$ is a high-affinity NAD ${ }^{+}$-dependent enzyme that operates exclusively as an oxidase inactivating biologically active glucocorticoids cortisol and corticosterone to their 11-oxo derivatives cortisone and 11-dehydrocorticosterone respectively (Stewart \& Krozowski 1999). In contrast, 11HSD1 is a low-affinity NADP(H)-dependent oxidoreductase whose reductase activity has been found in various intact cells (Seckl \& Walker 2001), but alterations in the $\mathrm{NADP}^{+} / \mathrm{NADPH}$ redox potential governed by the metabolism of glucose-6-phosphate via hexose-6-phosphate dehydrogenase seem to determine whether 11HSD1 operates as a reductase or an oxidase (Hewitt et al. 2005). Thus, 11HSD2 decreases the local concentration of active glucocorticoids, whereas 11HSD1 increases it due to regeneration of biologically active steroids from the circulating inactive 11-oxo metabolites or decreases it due to oxidation of active glucocorticoids (Stewart \& Krozowski 1999, Seckl \& Walker 2001, Hewitt et al. 2005). Exposure to pro-inflammatory stimuli such as TNF- $\alpha$ and IL-1 $\beta$ increases 11HSD1 expression and enzymatic activity in some cells, while inducing a decrease of 11HSD2 in others (Cai et al. 2001, Cooper et al. 2001, Heiniger et al. 2001, Thieringer et al. 2001, Tomlinson et al. 2001). The biological significance of this process was shown recently (Escher et al. 1997, Thieringer et al. 2001, Zhang et al. 2005).

With regard to the colon, 11HSD2 is expressed in epithelial cells, whereas 11HSD1 is localized in the cells of lamina propria (Whorwood et al. 1994). This matches with the findings of 11HSD1 in fibroblasts (Hammami \& Siiteri 
1991), macrophages (Thieringer et al. 2001), and lymphocytes (Zhang et al. 2005). Consistent with the effect of TNF- $\alpha$ and IL- $1 \beta$ on 11 HSD 1 and 11 HSD2, we have shown in a rat model of colitis that 11HSD1 mRNA expression and 11-reductase activity increased, whereas 11HSD2 mRNA expression and 11-oxidase activity decreased during intestinal inflammation (Bryndová et al. 2004). Considering that colitis is accompanied by activation of mucosal immune cells and increased recruitment of leucocytes from the vascular space (Elson et al. 1995), one can hypothesize that the link between the upregulation of colonic 11HSD1 mRNA and the increased ability of the tissue to reduce 11-dehydrocorticosterone to corticosterone might be the cells of the intestinal immune system. To address this question, we used the dextran sulfate model of murine colitis and studied the changes of 11HSD1 in colon and immune cells during intestinal inflammation.

\section{Materials and Methods}

Animals and preparation of immune cells

Female 3-month-old mice Balb/c (Velaz, Prague, Czech Republic) were used in this study. Experimental colitis was induced by adding 3\% (w/v) dextran sulfate sodium (DSS, MW 36 000-50 000; ICN Biomedicals Inc., Cleveland, Ohio, USA) in drinking water (Okayasu et al. 1990). Mice were treated with DSS for 7 days and subsequently killed. Control animals received only tap water. The mice were killed by decapitation and the colon, spleen, and mesenteric lymph nodes were excised. Macrophages were collected by a peritoneal lavage and intraepithelial lymphocytes (IEL) as originally described by Lefrancois (1992) with some modifications. Briefly, the inflamed part of colon was dissected and the lumen gently flushed with cold physiological saline $\left(4^{\circ} \mathrm{C}\right)$. The intestine was then incised longitudinally and cut into $5 \mathrm{~mm}$ pieces. The pieces were incubated in flasks containing RPMI-1640 medium supplemented with fetal bovine serum $(12 \cdot 5 \%)$ for $20 \mathrm{~min}$ at $37{ }^{\circ} \mathrm{C}$ with stirring. The incubation step was repeated thrice, the supernatants were combined, and IEL were separated from epithelial cells by discontinuous Percoll gradient at the interface 67\%/44\%. The harvested cells were washed in RPMI medium and used for further analysis.

The animal study was approved by the Animal Care and Use Review Committee of the Czech Academy of Sciences.

\section{Evaluation of colitis}

The clinical assessment of DSS-treated animals included body weight, colon length, evaluation of stool consistency, and the presence of blood in the stool. A clinical disease activity index representing the sum of separate scores ranging from 0 to 4 was calculated using the following parameters: body weight decrease $(0$, less than $5 \%$ decrease; $1,5-10 \% ; 2,10-20 \% ; 4$, more than 20\%), stool consistency (solid 0, loose 2, diarrhea 3 ), and bleeding (none 0 , macroscopic in colon 2, blood adhering to the anus 4) as described previously (Bendjelloul et al. 2000).

\section{Quantitative analysis of $11 \mathrm{HSD}$ and cytokine RNA}

Total RNA from the colon was extracted by the guanidinium thiocyanate method. The isolated RNA was treated with DNase (Promega) to remove potential contamination by genomic DNA as mentioned earlier (Mazancová et al. 2003). Total RNA from the spleen, mesenteric lymph nodes, macrophages, and IEL was obtained using GeneElute Mammalian Total RNA Miniprep Kit (Sigma). cDNA was synthesized from $5 \mu \mathrm{g}$ RNA and M-MLV Reverse Transcriptase reagents (Invitrogen $\mathrm{GmbH}$ ). Amplification of the target cDNA was performed in the LightCycler (Roche) as previously reported (Mazancová et al. 2005) using QuantiTect Sybr Green PCR Kit (Qiagen $\mathrm{GmbH}$ ) and the primers given in Table 1. Results were analyzed with LightCycler software using the second derivative maximum method to set $C_{\mathrm{p}}$ For the quantification of the target genes 11HSD1, 11HSD2, $T N F-\alpha$, and $I L-1 \beta$, we performed the quantitative comparison of several candidate reference genes to select the most stable genes for gene normalization. The panel of five reference genes generally used in many physiological and pathophysiological conditions, such as $\beta$-actin $(A C T B)$, hypoxanthine phosphoribosyltransferase 1 (HPRT1),

Table 1 Primers used for PCR

\begin{tabular}{|c|c|c|}
\hline & Sense $\left(5^{\prime} \rightarrow 3^{\prime}\right)$ & Antisense $\left(5^{\prime} \rightarrow 3^{\prime}\right)$ \\
\hline \multicolumn{3}{|l|}{ Gene } \\
\hline $11 H S D 1$ & GGTAGTGTCTCGCTGCCTTGAA & CACGTTGACCTTGGTTATGTAGAGTT \\
\hline $11 \mathrm{HSD} 2$ & CCGGTTGTGACACTGGTTTTG & GGGGTATGGCATGTCTCСTG \\
\hline$T N F-\alpha$ & GGACAAGGCTGCCCCGACTAC & TCTGAGCCATAATCCССТTTC \\
\hline$I L-1 \beta$ & TCCCAAGCAATACCCAAAGAAGAA & ATCAGAGGCAAGGAGGAAACACAG \\
\hline$\beta$-actin & GAACCCTAAGGCCAACCGTGAAAAGAT & ACCGCTCGTTGCCAATAGTGATG \\
\hline Ppib & AGGGGAGATGGCACAGGAGGAAAGAGC & ACCCAGCCAGGCCCGRAGTGC \\
\hline EF1a & TGACAGCAAAAACGACCCACCAAT & GGGCCATCTTCCAGCTTCTTACCA \\
\hline$R P 13 A$ & CTCCCGAGGCCССТАCСАСТT & GGCCTTTTCCTTCCGTTTCTCCTC \\
\hline HPRT & GCAGTCCCAGCGTCGTG & TAATGTAATCCAGCAGGTCAGC \\
\hline
\end{tabular}


ribosomal protein L13a $(R P L 13 A)$, elongation factor $1 \alpha$ (EF1A), and peptidylpropyl isomerase B (cyclophilin B; PPIB), were tested (Table 1). Because of the high concentration of $\beta$-actin and 11HSD2, the samples were diluted $1 / 1000$ before analyses of these RNA species. For other analyses, 1/10 prediluted cDNA was used as a template for PCR. Calibration curves were generated for each pair of primers from serial dilutions of standard cDNA. After statistical analysis of reference genes, the data of target gene expression were normalized according to the normalization factor calculated by the geNorm applet (Vandesompele et al. 2002).

The expression of 11HSD1 mRNA in IEL was determined by the ABI PRISM 7000 Sequence Detection System (Applied Biosystems, Foster City, CA, USA). The probes and primers used for this experiment were developed as TaqMan Gene Expression Assays by Applied Biosystems. The reaction was carried out in a final volume of $20 \mu \mathrm{l}$ using TaqMan Universal PCR Master Mix with AmpEraseUNG (Applied Biosystems) and Expression Assay. Target 11HSD1 mRNA was achieved using calibration curve method and the amount of mRNA was normalized to the level of $18 \mathrm{~S}$ rRNA (Bas et al. 2004).

\section{Enzyme activity assays}

Colon homogenates were prepared in ice-cold buffers containing $10 \mathrm{mM}$ Tris, $250 \mathrm{mM}$ sucrose $(\mathrm{pH} 8 \cdot 5$; 11HSD2 assay) or $10 \mathrm{mM}$ Tris, $5 \mathrm{mM}$ EDTA, $0 \cdot 5 \%$ Triton X-100 (pH $7 \cdot 5 ; 11$ HSD 1 assay). After centrifugation at $500 \mathrm{~g}$ for $15 \mathrm{~min}$, the supernatant was obtained and protein concentration was measured using the Bradford technique (Bradford, 1976). 11HSD1 and 11HSD2 activities were measured as NADP ${ }^{+}$and $\mathrm{NAD}^{+}$-dependent $11 \beta$-oxidation of corticosterone according to Livingstone \& Walker (2003) and Gomez-Sanchez et al. (2003). 11HSD1 activity was measured in incubation buffer containing $50 \mathrm{mM}$ Tris, $100 \mathrm{mM} \mathrm{KCl}$, $1 \mathrm{mM} \mathrm{NADP}^{+}, 480 \mathrm{nM}$ corticosterone, and $20 \mathrm{nM}$ 1,2,6,7$\left[{ }^{3} \mathrm{H}\right]$ corticosterone $(\mathrm{pH} \quad 7 \cdot 5)$. 11HSD2 activity was determined in a similar way, with $50 \mathrm{mM}$ Tris, $100 \mathrm{mM}$

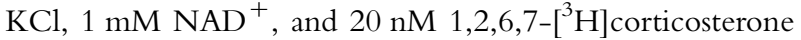
$(\mathrm{pH} 8 \cdot 5)$. The amounts of protein and the incubation times were determined in preliminary experiments to establish the optimal conditions, in order to work in the linear portion of the enzyme reaction. Steroids were extracted from the incubation buffer by SepPak cartridges (Waters, Milford, MA, USA) and separated by HPLC with on-line detection using a flow-cell detector (Radiomatic 150TR, Canberra Packard, Meriden, CT, USA). The separation was performed in a C18 column using a water methanol gradient (for details see Pácha et al. 2004).

\section{Data analysis}

All data are expressed as means \pm s.E.M. or medians with 25 th75 th percentile values. The distribution-fitting procedure according to Shapiro-Wilk's $W$-test of normality was applied and the comparison between the control animals and the mice with colitis was analyzed using unpaired Student's $t$-test or Mann-Whitney $U$-test. The values $P<0.05$ were considered statistically significant. For stability comparison of candidate reference genes and the calculation of normalization factor, the geNorm program was applied after conversion of $C_{\mathrm{P}}$ values into relative quantities (Vandesompele et al. 2002). Using this approach, the normalization factor based on two candidate reference genes was calculated. Statistical analysis was performed using the statistical software Statistica v.6 (StatSoft Inc., Tulsa, OK, USA).

\section{Results}

The mice with colitis developed loose stools or diarrhea associated with blood in the stool and decreased colon length and body weight. Mortality was $10 \%$. The index of disease activity is given in Table 2 .

To investigate whether metabolism of glucocorticoids is modulated in inflamed tissue, we used enzyme assay and quantitative reverse transcription (RT)-PCR. First, we evaluated the expression levels of five putative reference genes in the colon of healthy mice and in animals with colitis. These genes displayed a relatively wide range of $C_{P}$ (Fig. 1). Using the unpaired Student's $t$-test or Mann-Whitney U-test, significant differences in gene expression between healthy and inflamed colon were observed for EF1A and RPL13A. The geNorm program was then used to calculate the gene expression stability measure $M$ of the remaining genes and the normalization factor based on the geometric average of the two reference genes (Vandesompele et al. 2002). We found $\mathrm{ACTB}$ and PPIB to be the most convenient reference genes and thus these two genes were used for normalization of mRNA expression levels.

To determine whether 11 HSDs are modulated during inflammation, we measured colonic 11HSD1 and 11HSD2 mRNAs in control animals and in mice with colitis. As shown in Fig. 2, both groups of mice were found to express 11HSD1 and 11HSD2 transcripts and the inflammation affected the expression. Colitis upregulated 11HSD1 mRNA but did not

Table 2 Disease activity of DSS-induced colitis in colon

\section{Controls}

Symptom score Diarrhea score Blood score Body weight change Colon length

$$
\begin{aligned}
& 0 \\
& 0 \\
& 0 \\
& 2 \\
& 9
\end{aligned}
$$

\section{Acute colitis}

$8 \cdot 0(6 \cdot 0-10 \cdot 0)^{*}$ $3 \cdot 0(3 \cdot 0-3 \cdot 0)^{*}$ $4 \cdot 0(0 \cdot 0-4 \cdot 0)^{*}$ $-11 \cdot 4 \pm 1 \cdot 5^{*}$ $7 \cdot 3 \pm 0 \cdot 1^{*}$
The data are given as medians and 25th-75th percentile values (score values) or mean \pm S.E.M. (body weight change, colon length) based on records of 10 control and 9 DSS-treated animals. The score values were calculated as mentioned in Materials and Methods section, colon length is given in $\mathrm{cm}$, and body weight change is given by dividing body weight at day 7 by body weight at day 0 (starting body weight) and is expressed as a percentage. $* P<0.05$ compared with controls. 


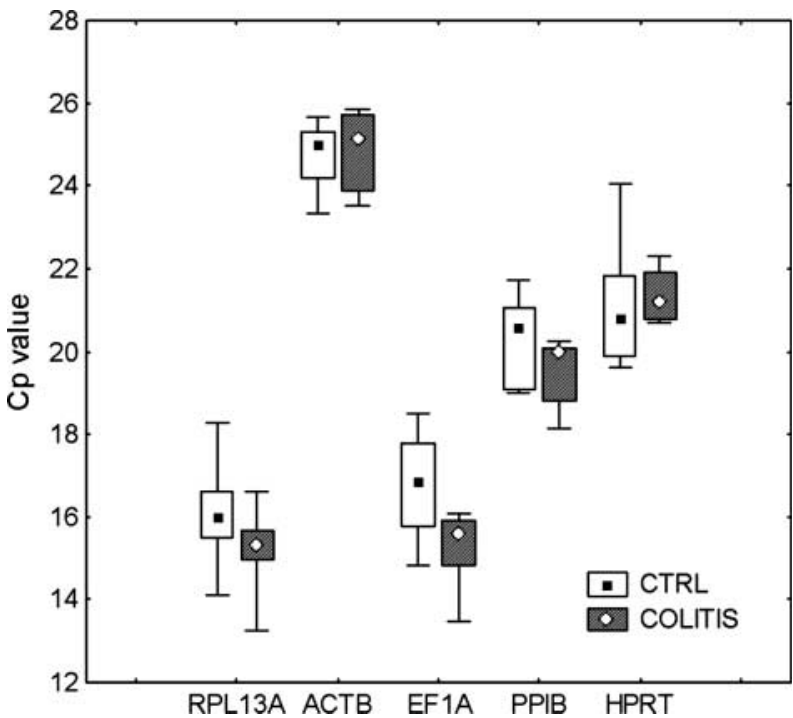

Figure 1 Expression levels of candidate reference genes in healthy and inflamed colon are shown as medians (points), 25th-75th percentiles (boxes), and ranges (whiskers). For the analyses, 1/1000 (ACTB) or $1 / 10$ pre-diluted CDNA (RPL3A, EF1A, PPIB, and HPRT) was used as a template for PCR.
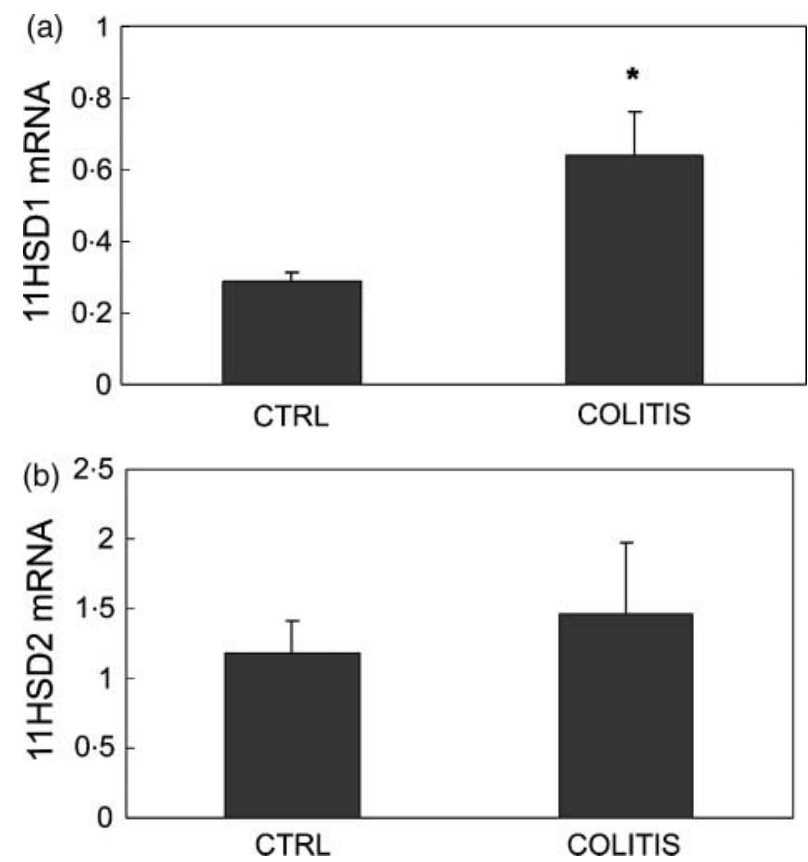

Figure 2 (a) Colonic 11HSD1 mRNA and (b) 11HSD2 mRNA levels in control mice and in animals with colitis. The relative expression levels were normalized against normalization factor from the two most stable reference genes provided by geNorm (for details see the text). The data are given as means \pm s.E.M. (control (CTRL), $n=10$; colitis, $n=9)$ ). ${ }^{P}<0 \cdot 05$ compared with controls.
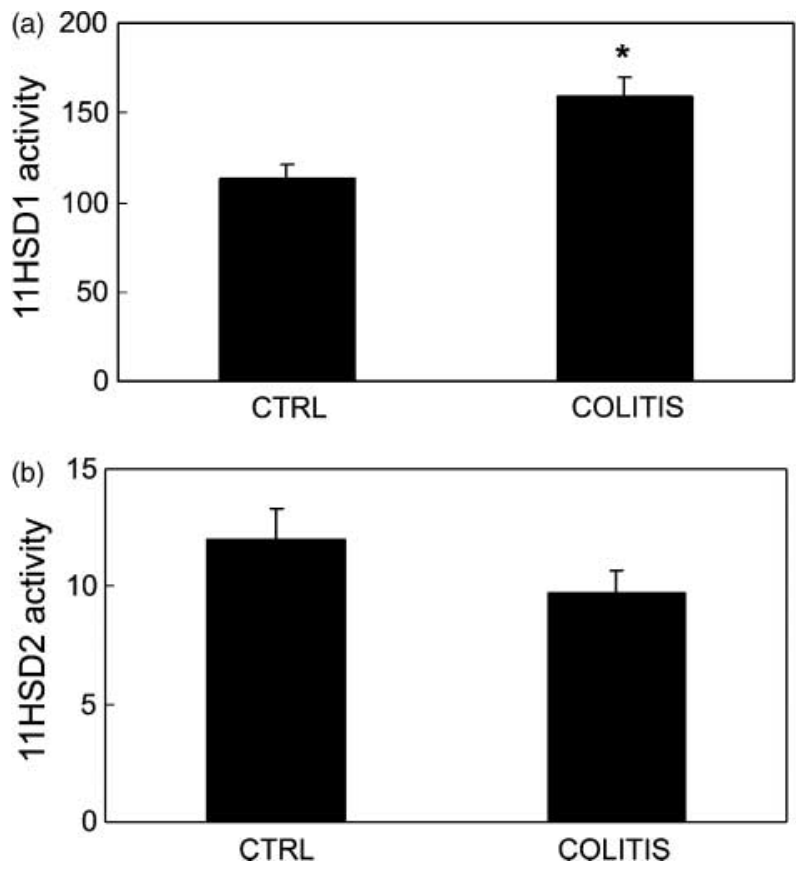

Figure 3 (a) $\mathrm{NAD}^{+}$- and (b) $\mathrm{NADP}^{+}$-dependent $11 \mathrm{HSD}$ activity in colonic homogenates of control mice and animals with colitis. Values are means \pm s.E.M. (control (CTRL), $n=10$; colitis, $n=10$ ). $11 \mathrm{HSD}$ activity is given in picomoles of corticosterone per hour per mg protein. ${ }^{*} P<0 \cdot 05$ compared with controls.

significantly modulate the levels of $11 \mathrm{HSD} 2 \mathrm{mRNA}$. To test whether the changes in transcript levels reflect changes in 11HSD1 and 11HSD2 enzyme activities, we used a colonic homogenate assay to analyze the $\mathrm{NAD}^{+}{ }_{-}$and $\mathrm{NADP}^{+}{ }_{-}$ dependent conversion of corticosterone to 11-dehydrocorticosterone. The colon of controls and the mice with colitis had similar level of $\mathrm{NAD}^{+}$-dependent 11HSD activity, but $\mathrm{NADP}^{+}$-dependent $11 \mathrm{HSD}$ activity was significantly increased in inflamed tissue (Fig. 3). To verify the presence of colonic inflammation in this tissue, we analyzed gene expression of pro-inflammatory cytokines, TNF- $\alpha$ and IL-1 $\beta$ mRNAs. As shown in Table 3, the level of IL-1 $\beta$ transcript was significantly increased in inflamed colon but the level of TNF- $\alpha$ transcript was changed much less, in a similar way as in the study of Egger et al. (2000) and Kwon et al. (2005).

Next, we evaluated the changes in the level of 11HSD1 mRNA in the cells of gut-associated lymphatic tissue. There was a significant increase in 11HSD1 mRNA in IEL isolated

Table 3 Expression of TNF- $\alpha$ and IL- $1 \beta$ mRNAs in colon

$\begin{array}{lll}\text { TNF- } \alpha \text { mRNA } & 0 \cdot 202 \pm 0 \cdot 063 & 0 \cdot 258 \pm 0 \cdot 61 \\ \text { IL-1 } \beta \text { mRNA } & 0 \cdot 023 \pm 0 \cdot 002 & 0 \cdot 356 \pm 0 \cdot 183^{*}\end{array}$

The data are given as means \pm s.E.M. of 10 control and 9 DSS-treated animals. The expression of cytokines is given in arbitrary units. ${ }^{*} P<0 \cdot 05$ compared with controls. 


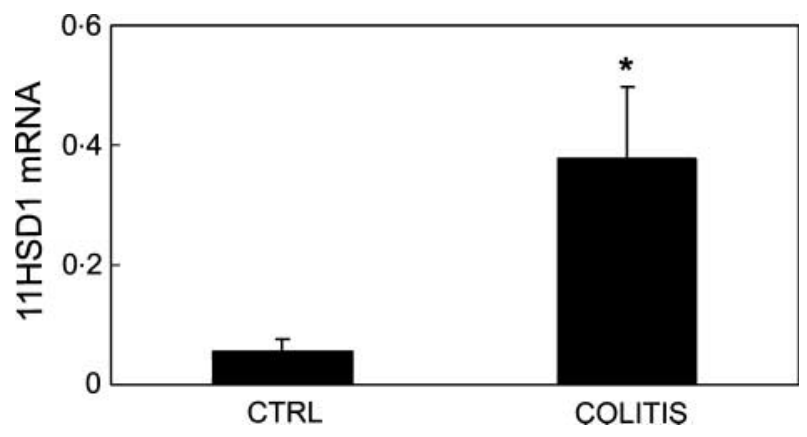

Figure 4 The relative expression levels of 11HSD1 mRNA in murine intestinal intraepithelial lymphocytes during DSS-induced colitis. Quantification of 11 HSD1 gene expression was performed relative to the expression of $18 \mathrm{~S}$ rRNA. $* P<0 \cdot 05$ compared with controls (control (CTRL), $n=5$; colitis, $n=9$ ).

from animals with colitis (Fig. 4). Consistent with upregulation of 11HSD1 mRNA in IEL, the lymphatic mesenteric nodes that contain large numbers of lymphocytes coming from the intestine demonstrated upregulation of 11HSD1 mRNA (Fig. 5), whereas 11HSD2 transcript was undetectable in the same nodes. In contrast to mesenteric lymph nodes, 11HSD1 transcript in spleen was not changed during colitis. Finally, to establish the potential contribution of macrophages to upregulation of colonic 11HSD1 during inflammation, the peritoneal macrophage 11HSD1 transcript was quantified. 11HSD1 mRNA was detectable in macrophages, but this transcript was not affected by colitis (controls: $0 \cdot 56 \pm 0 \cdot 05(n=10)$; colitis: $0 \cdot 48 \pm 0 \cdot 04(9))$. Taken together, these findings demonstrate similar changes in 11HSD1 mRNA in the colon, mesenteric lymphatic nodes, and IEL, but not in the spleen and peritoneal macrophages.

\section{Discussion}

The present study revealed that inflammation is associated with changes in 11HSD1 mRNA expression and enzyme activity in

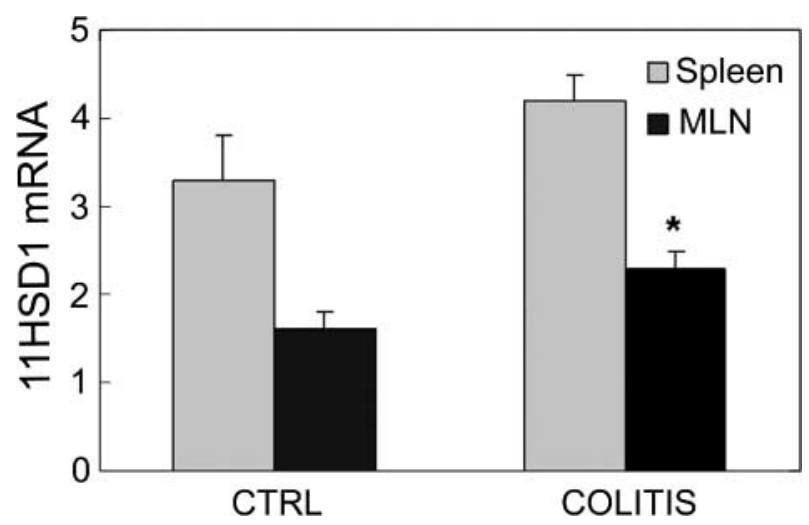

Figure 5 Expression of 11HSD1 in mesenteric lymph nodes (MLN) and spleen. The values were expressed as mentioned in Fig. 2.

${ }^{*} P<0 \cdot 05$ compared with controls (control, $n=10$; colitis, $n=9$ ). colon. The inflamed colon upregulated 11HSD1 transcript and $\mathrm{NADP}^{+}$-dependent $11 \mathrm{HSD}$ activity without any significant changes in $11 \mathrm{HSD} 2$ transcript and $\mathrm{NAD}^{+}{ }_{-}$ dependent 11HSD activity. As 11HSD2 is expressed only in epithelium, whereas 11HSD1 is expressed in the submucosal layer (Whorwood et al. 1994), it is likely that changes in $11 \mathrm{HSD} 1$ proceed in the intestinal compartment of lamina propria or gut-associated lymphatic tissue and not in the epithelium. 11HSD1 was found in macrophages (Thieringer et al. 2001), $T$ cells (Zhang et al. 2005), and fibroblasts (Hammami \& Siiteri 1991), and we have found an increased level of 11HSD1 mRNA in IEL and mesenteric lymphatic nodes of mice with colitis. The question is what is the direction of 11HSD1 reaction in intact cells in vivo?. This direction (11 $\beta-$ reduction or $11 \beta$-oxidation) depends on the ratio of NADPH/ $\mathrm{NADP}^{+}$, which is determined by hexose-6-phosphate dehydrogenase and pentose-phosphate pathway (Atanasov et al. 2004, McCormick et al. 2006). Thus, it is difficult to anticipate the reaction direction of 11HSD1 in inflamed colon. Considering that 11HSD1 operates as a reductase in activated macrophages (Gilmour et al. 2006), lymphocytes (Zhang et al. 2005), and dendritic cells (Freeman et al. 2005), it is likely that colonic 11HSD1 is increased by a shift in favor of the reductase activity. Further studies are needed to clarify the role of 11HSD isoforms of colonic wall in vivo by cellular distribution of 11HSD in cell types of colonic mucosa and submucosa during inflammation and the effect of NADPH depletion during oxidative stress on the direction of the reaction catalyzed by 11HSD1 in immune cells.

The exact mechanism of inflammation induced by DSS is not yet fully elucidated, but the pathogenesis seems to depend on the interaction between local immune reaction and environmental factors because animal models of inflammatory bowel disease reared in germfree conditions did not develop the disease (Tlaskalová-Hogenová 1997, Hudcovic et al. 2001, Elson \& Cong 2002). Drinking of DSS generates in murine colon the upregulation of pro-inflammatory cytokines as well as reactive oxygen and nitrogen species and infiltration by polymorphonuclear and mononuclear cells (Okayasu et al. 1990, Kojouharoff et al. 1997, Arai et al. 1998). Previous data and our findings suggest that these processes are accompanied by upregulation of 11HSD1 in the cells of gutassociated lymphatic tissue. First, activated macrophages and lymphocytes acquire increased capacity of glucocorticoid reactivation via 11HSD1 (Zhang et al. 2005, Gilmour et al. 2006). Secondly, our data show that $\mathrm{NADP}^{+}$-dependent but not $\mathrm{NAD}^{+}$-dependent activity is increased in inflamed colon. Thirdly, the level of 11HSD1 transcript is increased not only in inflamed colon but also in IEL and in mesenteric lymphatic nodes. This upregulation of 11HSD1 is presumably induced by the pro-inflammatory cytokines, whose levels of transcript and protein are increased in colon of DSS-treated mice (Arai et al. 1998, Egger et al. 2000, Obermeier et al. 2002, Kwon et al. 2005). The cytokines TNF- $\alpha$ and IL- $1 \beta$ are known to increase 11HSD1 mRNA and 11-reductase activity in various cell types, such as glomerular mesangial cells (Escher et al. 
1997), osteoblasts (Cooper et al. 2001), adipocytes (Tomlinson et al. 2001), and aortic smooth muscle cells (Cai et al. 2001). In addition, pro-inflammatory cytokines are important inducers of nitric oxide generation in macrophages and intestinal epithelial cells, and the interaction between the NO system and the 11HSDs has recently been demonstrated (Kolios et al. 1996, Saito \& Nakano 1996, Sun et al. 1997, Ruschitzka et al. 2001).

It is well recognized that glucocorticoids effectively modulate a number of immunological processes, including positive or negative regulation of cytokine production (Hennebold et al. 1996, Ashwell et al. 2000). Therefore, changes in the metabolism of glucocorticoids within peripheral lymphatic organs and in immune cells could modulate not only the suppression of cell activation by proinflammatory cytokines but also other immunomodulatory processes (Elenkov \& Chrousos 1999, McKay \& Cidlowski 1999). Using glomerular mesangial cells exposed to IL-1 $\beta$ and TNF- $\alpha$, it was demonstrated that the release of phospholipase A2, a key enzyme producing inflammatory mediators, is decreased by 11HSD1 activity (Escher et al. 1997). Similarly, the pharmacological inhibition of 11 HSD in vivo greatly enhanced the susceptibility to progressive bacterial diseases and these changes in resistance following 11 HSD inhibition correlated with changes in the patterns of inducible cytokines in lymphocytes and macrophages (Hennebold et al. 1997). Given the central role of 11HSD1 in glucocorticoid action, we can speculate that the increased expression of this enzyme may serve to enhance the exposure of immune cells to active glucocorticoids via the paracrine and/or intracrine pathway.

In summary, our observations are consistent with the notion that inflammation is associated with changes in 11HSD1. Although the mechanism and accurate function of 11HSD1 upregulation is equivocal, the findings suggest that the bioavailability of glucocorticoids in inflamed colon differs from the healthy tissue.

\section{Acknowledgements}

This work was supported by grants from the Ministry of Health of the Czech Republic (NR/8576-3) and from the Academy of Sciences (KJB 5011 402, A 5020 205, S 500 200572). The authors gratefully acknowledge the contribution of $\mathrm{D}$ Sokol during the preliminary experiments and the technical assistance of Mrs I Mezteková and I Muricová. The authors declare that there is no conflict of interest that would prejudice the impartiality of this scientific work.

\section{References}

Arai Y, Takanashi H, Kitagawa H \& Okayasu I 1998 Involvement of interleukin-1 in the development of ulcerative colitis induced by dextran sulfate sodium in mice. Cytokine 10 890-896.
Ashwell JD, Lu FWM \& Vacchio MS 2000 Glucocorticoids in T cell development and function. Annual Reviews of Immunology 18 309-345.

Atanasov AG, Nashev LG, Schweizer RAS, Frick C \& Odermatt A 2004 Hexose-6-phosphate dehydrogenase determines the reaction direction of $11 \beta$-hydroxysteroid dehydrogenase type 1 as an oxoreductase. FEBS Letters 571 129-133.

Bas A, Forsberg G, Hammarström S \& Hammarström M-L 2004 Utility of the housekeeping genes $18 \mathrm{~S}$ rRNA, $\beta$-actin and glyceraldehyd-3-phosphatedehydrogenase for normalization in real-time quantitative reverse transcriptase-polymerase chain reaction analysis of gene expression in human T lymphocytes. Scandinavian Journal of Immunology 59 566-573.

Bendjelloul F, Malý P, Mandys V, Jirkovská M, Prokešová L, Tučková L \& Tlaskalová-Hogenová H 2000 Intercellular adhesion molecule-1 (ICAM-1) deficiency protects mice against severe forms of experimentally induced colitis. Clinical and Experimental Immunology 119 57-63.

Besedovsky HO \& del Rey A 1996 Immune-neuro-endocrine interactions: facts and hypotheses. Endocrine Reviews 17 64-102.

Bradford MM 1976 A rapid and sensitive method for the quantitation of microgram quantities of protein utilizing the principle of protein dyebinding. Analytical Biochemistry 72 248-254.

Bryndová J, Žbánková Š, Kment J \& Pácha J 2004 Colitis up-regulates local glucocorticoid activation and down-regulates inactivation in colonic tissue. Scandinavian Journal of Gastroenterology 39 549-553.

Cai T-Q, Wong B, Mundt SS, Thieringer R, Wrigh SD \& HermanowskiVosatka A 2001 Induction of $11 \beta$-hydroxysteroid dehydrogenase type 1 but not type 2 in human aortic smooth muscle cells by inflammatory stimuli. Journal of Steroid Biochemistry and Molecular Biology 77 117-122.

Cooper MS, Bujalska I, Rabbitt E, Walker EA, Bland R, Sheppard MC, Hewison M \& Stewart PM 2001 Modulation of 11 $\beta$-hydroxysteroid dehydrogenase isozymes by proinflammatory cytokines in osteoblasts: an autocrine switch from glucocorticoid inactivation to activation. Journal of Bone and Mineral Research 16 1037-1044.

Egger B, Bajaj-Elliott M, MacDonald TT, Inglin R, Eysselein VE \& Büchler MW 2000 Characterization of acute murine dextran sodium sulphate colitis: cytokine profile and dose dependency. Digestion 62 240-248.

Elenkov IJ \& Chrousos GP 1999 Stress hormones, Th1/Th2 patterns, pro/anti-inflammatory cytokines and susceptibility to disease. Trends in Endocrinology and Metabolism 9 359-368.

Elson CO \& Cong Y 2002 Understanding immune-microbial homeostasis in intestine. Immunology Research 26 87-94.

Elson CO, Sartor RB, Tennyson GS \& Riddell RH 1995 Experimental models of inflammatory bowel disease. Gastroenterology 109 1344-1367.

Escher G, Galli I, Vishwanath BS, Frey BM \& Frey FJ 1997 Tumor necrosis factor $\alpha$ and interleukin $1 \beta$ enhance the cortisone/cortisol shuttle. Journal of Experimental Medicine 186 189-198.

Freeman L, Hewison M, Hughes SV, Evans KN, Hardie D, Means TK \& Chakraverty R 2005 Expression of $11 \beta$-hydroxysteroid dehydrogenase type 1 permits regulation of glucocorticoid bioavailability by human dendritic cells. Blood 106 2042-2049.

Gilmour JS, Coutinho AE, Cailhier JF, Man TY, Clay M, Thomas G, Harris HJ, Mullins JJ, Seckl JR, Savill JS et al. 2006 Local amplification of glucocorticoids by $11 \beta$-hydroxysteroid dehydrogenase type 1 promotes macrophage phagocytosis of apoptotic leukocytes. Journal of Immunology 176 7605-7611.

Gomez-Sanchez EP, Ganjam V, Chen YJ, Liu Y, Zhou MY, Toroslu C, Romero DG, Hughson MD, de Rodriguez A \& Gomez-Sanchez CE 2003 Regulation of $11 \beta$-hydroxysteroid dehydrogenase enzymes in the rat kidney by estradiol. Americam Journal of Physiology 285 E272-E279.

Hammami MM \& Siiteri PK 1991 Regulation of 11 $\beta$-hydroxysteroid dehydrogenase activity in human skin fibroblasts: enzymatic modulation of glucocorticoid action. Journal of Clinical Endocrinology and Metabolism 73 326-334.

Heiniger CD, Rochat MK, Frey FJ \& Frey BM 2001 TNF- $\alpha$ enhances intracellular glucocorticoid availability. FEBS Letters 507 351-356.

Hennebold JD, Ryu S-Y, Mu H-H, Galbraith A \& Daynes RA $199611 \beta$ Hydroxysteroid dehydrogenase modulation of glucocorticoid activities in lymphoid organs. American Journal of Physiology 270 R1296-R1306. 
Hennebold JD, Mu H-H, Poynter ME, Chen X-P \& Daynes RA 1997 Active catabolism of glucocorticoids by $11 \beta$-hydroxysteroid dehydrogenase in vivo is a necessary requirement for natural resistance to infection with Listeria monocytogenes. International Immunology 9 105-115.

Hewitt KN, Walker EA \& Stewart PM 2005 Minireview: hexose-6-phosphate dehydrogenase and redox control of $11 \beta$-hydroxysteroid dehydrogenase type 1 activity. Endocrinology 146 2539-2543.

Hudcovic T, Štěpánková R, Cebra J \& Tlaskalová-Hogenová H 2001 The role of microflora in the development of intestinal inflammation: acute and chronic colitis induced by dextran sulfate in germ-free and conventionally reared immunocompetent and immunodeficient mice. Folia Microbiologica $46565-572$.

Kojouharoff G, Hans W, Obermeier F, Mannel DN, Andus T, Scholmerich J, Gross V \& Falk W 1997 Neutralization of tumour necrosis factor (TNF) but not of IL-1 reduces inflammation in chronic dextran sulphate sodium-induced colitis in mice. Clinical and Experimental Immunology 107 353-358.

Kolios G, Robertson DA, Jordan NJ, Minty A, Caput D, Ferrara P \& Westwick J 1996 Interleukin-8 production by the human colon epithelial cell line HT-29: modulation by interleukin-13. British Journal of Pharmacology 119 351-359.

Kwon KH, Murakami A, Hayashi R \& Ohigashi H 2005 Interleukin-1 $\beta$ targets interleukin-6 in progressing dextran sulfate sodium-induced experimental colitis. Biochemical and Biophysical Research Communications 337 647-654.

Lefrancois LL 1992 Isolation of mouse small intestinal intraepithelial lymphocytes, Payer's patch and laminal propria cells. In Current Protocols in Immunology, pp 1-16. Eds JE Coligan, AM Kruisbeek, D Margulies, EM Shevach \& W Strober. New York: John Wiley and Sons.

Livingstone DEW \& Walker BW 2003 Is $11 \beta$-hydroxysteroid dehydrogenase type 1 a therapeutic target? Effects of carbenoxolone in lean and obese Zucker rats. Journal of Pharmacology and Experimental Therapeutics 305 $167-172$.

Mazancová K, Mikšík I, Kuneš J \& Pácha J 2003 Placental 11ß-hydroxysteroid dehydrogenase in Dahl and spontaneously hypertensive rats. American Journal of Hypertension 16 401-406.

Mazancová K, Kopecký M, Mikšík I \& Pácha J 2005 11ß-hydroxysteroid dehydrogenase in the heart of normotensive and hypertensive rats. Journal of Steroid Biochemistry and Molecular Biology 94 273-277.

McCormick KL, Wang X \& Mick GJ 2006 Evidence that the 11 $\beta$ hydroxysteroid dehydrogenase (11ß-HSD1) is regulated by pentose pathway flux. Studies in rat adipocytes and microsomes. Journal of Biological Chemistry 281 341-347.

McKay LI \& Cidlowski JA 1999 Molecular control of immune/inflammatory responses: interactions between nuclear factor- $\mathrm{\kappa B}$ and steroid receptorsignalling pathways. Endocrine Reviews 20 435-459.

Obermeier F, Dunger N, Deml L, Herfarth H, Scholmerich J \& Falk W 2002 CpG motifs of bacterial DNA exacerbate colitis of dextran sulfate sodiumtreated mice. European Journal of Immunology 32 2084-2092.

Okayasu I, Hatakeyama S, Yamada M, Ohkusa T, Inagaki Y \& Nakaya R 1990 A novel method in the induction of reliable experimental acute and chronic ulcerative colitis in mice. Gastroenterology 98 694-702.
Pácha J, Mikš́k I, Mrnka L, Zemanová Z, Bryndová J, Mazancová K \& Kučka M 2004 Corticosterone regulation of colonic ion transport during postnatal development: methods for corticosterone analysis. Physiological Research $\mathbf{5 3}$ S63-S80.

Ruschitzka F, Quaschning T, Noll G, deGottardi A, Rossier MF, Enseleit F, Hürlimann D, Lüscher T \& Shaw SG 2001 Endothelin 1 type A receptor antagonism prevents vascular dysfunction and hypertension induced by $11 \beta$-hydroxysteroid dehydrogenase inhibition. Role of nitric oxide. Circulation 103 3129-3135.

Saito S \& Nakano M 1996 Nitric oxide production by peritoneal macrophages of Mycobacterium bovis BCG-infected or non-infected mice: regulatory role of T lymphocytes and cytokines. Journal of Leukocyte Biology 59 908-915.

Seckl JR \& Walker BR 2001 Minireview: 11 $\beta$-Hydroxysteroid dehydrogenase type 1 - a tissue-specific amplifier of glucocorticoid action. Endocrinology 142 1371-1376.

Stewart PM \& Krozowski ZS 1999 11ß-hydroxysteroid dehydrogenase. Vitamins and Hormones 57 249-324.

Sun K, Yang K \& Challis JRG 1997 Differential regulation of 11ßhydroxysteroid dehydrogenase type 1 and 2 by nitric oxide in cultured human placental trophoblast and chorionic cell preparation. Endocrinology 138 4912-4920.

Thieringer R, Le Grand CB, Carbin L, Cai T-Q, Wong B, Wright SD \& Hermanowski-Vosatka A 2001 11ß-Hydroxysteroid dehydrogenase type 1 is induced in human monocytes upon differentiation to macrophages. Journal of Immunology 167 30-35.

Tlaskalová-Hogenová H 1997 Gnotobiology as a tool - an introduction. In Immunology Methods Manual, pp 1524-1529. Ed. I Lefkovits. London: Academic Press.

Tomlinson JW, Moore J, Cooper MS, Bujalska I, Shahmanesh M, Burt C, Strain A, Hewison M \& Stewart PM 2001 Regulation of expression of $11 \beta$-hydroxysteroid dehydrogenase type 1 in adipose tissue: tissue specific induction by cytokines. Endocrinology 142 1982-1989.

Vandesompele J, De Preter K, Pattyn F, Poppe B, Van Roy N, De Paepe A \& Speleman F 2002 Accurate normalization of real-time quantitative RT-PCR data by geometric averaging of multiple internal control genes. Genome Biology 3 (Reserch0034.1-Research0034.11).

Webster JI, Tonelli L \& Sternberg EM 2002 Neuroendocrine regulation of immunity. Annual Reviews of Immunology 20 125-163.

Whorwood CB, Ricketts ML \& Stewart PM 1994 Epithelial cell localization of type $211 \beta$-hydroxysteroid dehydrogenase in rat and human colon. Endocrinology 135 2533-2541.

Zhang TY, Ding X \& Daynes RA 2005 The expression of $11 \beta$ hydroxysteroid dehydrogenase type 1 by lymphocytes provides a novel means for intracrine regulation of glucocorticoid activities. Journal of Immunology 174 879-889.

Received in final form 25 July 2006

Accepted 11 August 2006

Made available online as an Accepted Preprint 12 September 2006 